\title{
Entrepreneurship as Experimentation
}

\section{Citation}

Kerr, William R., Ramana Nanda, and Matthew Rhodes-Kropf. "Entrepreneurship as

Experimentation." Journal of Economic Perspectives 28, no. 3 (Summer 2014): 25-48.

\section{Published Version}

http://pubs.aeaweb.org/doi/pdfplus/10.1257/jep.28.3.25

\section{Permanent link}

http://nrs.harvard.edu/urn-3:HUL.InstRepos:27336545

\section{Terms of Use}

This article was downloaded from Harvard University's DASH repository, and is made available under the terms and conditions applicable to Open Access Policy Articles, as set forth at http:// nrs.harvard.edu/urn-3:HUL.InstRepos:dash.current.terms-of-use\#OAP

\section{Share Your Story}

The Harvard community has made this article openly available.

Please share how this access benefits you. Submit a story.

Accessibility 


\title{
Entrepreneurship as Experimentation
}

\author{
William R. Kerr, Ramana Nanda, and Matthew \\ Rhodes-Kropf
}

A lthough the fundamental importance of entrepreneurship has been generally recognized by economists since at least Schumpeter (1911 [1934]; 1943),

it has not been the subject of substantial research and is more-or-less absent from standard textbooks. Over the last decade, however, entrepreneurship has flourished as a research topic within economics. As entrepreneurship emerges from the shadows, many central and unresolved questions linger: How should we define entrepreneurship? What are its key aspects? Is entrepreneurship about the next Skype or the next self-employed accountant? We assert in this paper that effective entrepreneurship—especially among high-growth ventures and for the economy as a whole-builds upon a process of experimentation in deep and nuanced ways.

Entrepreneurship is fundamentally about experimentation because the knowledge required to be successful cannot be known in advance or deduced from some set of first principles. As Hayek (1948) put it, "the solution of the economic problem of society is ... always a voyage of exploration into the unknown." For entrepreneurs, it can be virtually impossible to know whether a particular technology or product or business model will be successful, until one has actually invested in it.

Two interesting examples help frame the discussion. In 1999, the venture capital firms Sequoia Capital and Kleiner Perkins Caufield \& Byers each invested $\$ 12.5$ million in Google, a brand new startup that claimed to have a superior search engine. By the time Sequoia sold its stake in 2005, that investment was worth over

- William Kerr, Ramana Nanda, and Matthew Rhodes-Kropf are Associate Professors at Harvard Business School, Harvard University, Boston, Massachusetts, and Faculty Research Fellows at the National Bureau of Economic Research, Cambridge, Massachusetts. Their email addresses arewkerr@hbs.edu, RNanda@hbs.edu, and mrhodeskropf@hbs.edu.

${ }^{\dagger}$ To access the data Appendix, visit http://dx.doi.org/10.1257/jep.28.3.25

doi $=10.1257 /$ jep.28.3.25 
\$4 billion, returning 320 times the initial cost (Sahlman 2010). The staggering success should not obscure a key point-Google was by no means a sure-shot investment in 1999. The search algorithm space was already crowded and dominated by other players such as Yahoo! and Altavista. Google, founded by two students, might well have turned out to just be a "me too" investment. In fact, other venture capitalists had turned down the opportunity to invest in Google at the time. One such firm was Bessemer Ventures. Partner David Cowan, on being asked by a friend to meet with the two Google founders who had rented space in her garage, is believed to have quipped, "How can I get out of this house without going anywhere near your garage?" (Bessemer Venture Partners, no date). Over the years, Bessemer has been so successful that they playfully mock at their "anti-portfolio" of deals that they passed on (at http://www.bvp.com/portfolio/antiportfolio).

Not many investors are as candid about great opportunities that they have passed on, but more recently, Fred Wilson of Union Square Ventures has similarly written about his regret at passing on Airbnb, a startup that lets people rent rooms or homes to prospective guests online. Started in 2008, Airbnb currently lists 500,000 properties in more than 34,000 cities across 192 countries, far more than any hotel chain-thereby making it the largest lodging company and brand in the world (Levere 2013). Wilson (2011) explains Union Square Venture's decision to pass on the deal in 2009: "we couldn't wrap our heads around air mattresses on the living room floors as the next hotel room... . Others saw the amazing team that we saw, funded them, and the rest is history."

These two examples highlight several challenges associated with commercialization of new ideas, products, and technologies. First, the actual distribution of returns in such ventures has a low median value but very high variance (Scherer and Harhoff 2000; Hall and Woodward 2010). Most new ventures fail badly, but some turn out to be wildly successful. Second, even for professional investors or managers making resource allocation decisions, it is impossible to know in advance which ideas will work. As we describe in greater detail below, venture capital investors make their returns on the one investment out of many that turns out to be a wild success like Google or Airbnb. The vast majority of venture capital investments, however, return less than the face value of the investment.

How entrepreneurs and investors respond to these inherent challenges has important implications for their own success and also for the broader economy in terms of the "best ideas" being commercialized. To flesh out this point, it is important to separate two frames of reference regarding experimentation. The first relates to economic experimentation in a Darwinian sense, which is the natural starting point for most economists. In this conceptual model, new ventures compete with existing products and technologies, and the ensuing competition leads to the survival of the fittest, just as Google surpassed its early rivals due to its superior technology. This competition can be described as experimentation at the level of the economy. In settings where the best approach among several options is unknown, a great benefit of market-based economies is that winners are often chosen by consumers and competition. As Rosenberg (1994) has argued, one of the defining features 


\section{Table 1}

\section{US Venture Capital Statistics for 2010}

$\begin{array}{lc}\text { Number of active venture capital firms } & 462 \\ \text { Amount invested by venture capital firms } & \$ 22 \text { billion } \\ \text { Number of companies receiving venture capital investment } & 2,749 \\ \text { Number of companies receiving funding for first time } & 1,001 \\ \text { Share of dollars invested in Information Technology firms } & 51 \% \\ \text { Share of dollars invested in Life Science firms } & 27 \%\end{array}$

Source: Data from National Venture Capital Association, nvac.org.

of capitalism is the freedom it provides entrepreneurs to pursue novel approaches to value creation in the pursuit of economic gain. The promise of large rewards drives entrepreneurs to experiment with new ideas, helping to create a dynamic and growing economy. An institutional environment that facilitates experimentation is thus central to maintaining a vibrant entrepreneurial ecosystem (Dosi and Nelson 2010). This experimentation, combined with a willingness to let losing incumbents fail, is the underlying notion behind Schumpeter's (1943) process of "creative destruction."

While this Darwinian depiction is important and a natural starting point, a second reference point emphasizes that we should be cautious of assuming that market-based mechanisms can always serve as a guiding hand with respect to experimentation. As in the Google example, it is often very difficult to know whether a particular technology or venture will succeed until one has made an investment. Moreover, the investments to obtain this vital information can be nontrivial: in Google's case, a total of $\$ 25$ million was invested in the first round. Table 1 documents some basic facts about the venture capital industry, including the number of active investors. Given the relatively small number of financiers that invest in this sector, it is easy to imagine scenarios where Google or other highly productive investments fail to receive the required funding.

In an entrepreneurial setting, where the benefit of pursuing different approaches is not clear and the costs of tests are expensive, each individual endeavor is also engaged in a process of experimentation. As these experiments provide information about the likelihood of ultimate success, entrepreneurs and investors gain information about whether to continue the project. However, the investment and continuation decisions for entrepreneurs are often not made in a competitive Darwinian contest, because the decisions to invest further or shut down a firm are often made by only a few investors, well before startups can compete in the product market or have positive cash flow. Moreover, the decisions are made by discrete individuals, often in venture capital firms or other early-stage financing vehicles, whose actions are impacted by a myriad of incentive, agency, and coordination problems. Thus, the extent to which the best idea goes forward may depend on factors such as the organizational structure or incentive system of the firm where the investor is based, available information sets (for example, access to certain networks), 
coordination costs, and other such frictions. Taken together, these factors affect how much experimentation is undertaken in the economy and also the trajectory of experimentation, with potentially very deep economic consequences.

The lens of experimentation has implications for what types of innovations will occur, who will pursue them and when. As Stern (2005) argued, "a favorable environment for entrepreneurship and a high level of economic experimentation go hand in hand." Although experiments can be conducted in large companies or in the public sector, new technologies and innovative products are often commercialized by entrepreneurs and often cluster at particular times. We argue that the costs and constraints on the ability to experiment alter the type of organizational form surrounding innovation and influence when innovation is more likely to occur.

This article considers these costs and constraints to experimentation by investors and the implications that these issues have on the type of entrepreneurship across time and across economies. We start with a micro-level examination of experimentation and focus on the processes used by investors to experiment and the issues that individual firms face. We then turn to the macro perspective of the economy and the policies that shape entrepreneurship and its effectiveness.

\section{A Closer Look at the Process of Experimentation}

High-impact entrepreneurship requires, almost by definition, going against the grain. Rajan (2012) argues that an entrepreneur "must be willing to strike out, largely on the basis of intuition, on courses of action in direct opposition to the established settled patterns." A consequence of this setting is extreme uncertainty about whether a particular technology, product, or business model will be successful. This uncertainty is fundamentally different from risk, as Knight (1921) stressed. With risk, such as placing money on a spin of a roulette wheel, one can define exact probabilities and expected values. With Knightian uncertainty, these probabilities are not known, and even the form of the potential outcomes may be unclear. For example, looking forward from today, at what rate will electric cars, if at all, replace traditional automobiles and how will the supporting infrastructure for battery recharging be designed? What will be the impact of nascent augmented reality technologies for how humans interact? Which, if any, of the several current ideas to cure cancer will be successfully commercialized?

In this environment of tremendous uncertainty, experimentation allows entrepreneurs and investors to assess and commercialize projects without investing the full amount. Crucially, experimentation offers more than just a possibility of higher returns-it also allows entrepreneurs and investors to pursue projects that are not feasible in an all-or-nothing bet. For example, consider a project that requires $\$ 110$ to commercialize and will be worth $\$ 0$ with 99 percent probability or $\$ 10,000$ with 1 percent probability. This project will not be pursued, because its expected value is negative $(-\$ 10)$. But imagine we can conduct an experiment that will reveal if the project has a 10 percent chance of working. (Suppose further that the probability 
of the experiment having a positive outcome is only 10 percent, so that in this example the 1 percent chance of overall success is unchanged.) If the experiment gives a positive signal, the project has a larger expected value of $\$ 890$. Thus, as long as the experiment costs less than $\$ 89$ (10 percent $\times \$ 890)$, the experiment should be conducted, with the project then being either shut down or commercialized based upon the results.

This simple example provides insights into many features of the entrepreneurial landscape, as we elaborate below. The test resolves uncertainty about the project's potential and creates a real option value for further pursuit. Thus, experimentation is particularly valuable in cases where initial information can be especially informative about the overall quality of the project and this information is cost effective to obtain. ${ }^{1}$

The example also illustrates that the costs of experimenting are important. Our simple example was phrased in terms of the direct costs of conducting the test. More broadly, important indirect costs must be borne by either the investor or entrepreneur when they fail. Even if direct costs are small, significant indirect costs like a stigma of failure (Landier 2005) may still prevent entrepreneurs from pursuing otherwise valuable tests if they only have a 10 percent chance to succeed. Moreover, the ability to document and transmit the results of experiments is important, because the information from the experiment is only valuable if it can be acted upon. Can an investor use the information to decide to provide the follow-on investment required to realize the project? The framework also begins to highlight the distinct roles of the entrepreneur and the investor.

We trace these features out next by first looking more closely at the economics of a venture capital firm. This setting provides a powerful archetype of high-impact entrepreneurship more broadly and the role of experimentation. We then discuss frictions to experimentation that are observed in the economy and the extent to which agents are able to address them.

\section{The Economics of Experimentation in a Venture Capital Firm}

The economics and structure of a venture capital firm provide insights into entrepreneurship as experimentation (Sahlman 1990). A crucial starting point is the recognition that venture capital firms do not simply act as a portfolio of risky startups. While the portfolio nature of a venture capital firm is important, it is quite distinct from what is observed in stock market mutual funds, for example, where the portfolio is designed to smooth out the idiosyncrasies of individual stocks. Venture capital firms are better thought of as conducting a portfolio of tests across a number of highly uncertain ideas with skewed economics (similar to the example described above). In most cases, the tests come out negative. In fact, the majority of venture-capital-backed firms fail, despite the investments made into them by highly skilled investors. Once venture capital firms identify the

\footnotetext{
${ }^{1}$ Weitzman (1979) introduces and analyzes the optimal search behaviors under these uncertainties.
} 
cases that deliver positive test results, however, they pursue them aggressively and invest ever larger amounts on the promising candidates to scale them up. Whereas mutual fund investors do not need to be an early investor in a company in order to be allowed to invest more later, this is precisely the way that venture capital firms aim to make money-by starting small and owning a larger share of the firms that turn out to be successful, while attempting to cut their losses on the unsuccessful ones as early as possible. ${ }^{2}$

Some simple calculations document these skewed returns using data on all venture capital investments in the United States. Using data from Thompson Venture Economics, we identify all startup ventures that received their first round of early-stage financing for the years between 1985 and 2009. We calculate both the total investment made by venture capital investors in each of these firms, as well as the gross return at the time of exit-either through an acquisition deal, an initial public offering, or bankruptcy. We then group each of these startups based on their economic return to investors at the time of exit-that is, the ratio of the gross return at the point of exit divided by the total amount invested in the startup. About 55 percent of startups that received venture capital over this period were terminated at a loss, and only 6 percent of them returned more than five times their investment. This 6 percent group, however, was extremely successful and together accounted for about 50 percent of the gross return generated over the period. $\|^{[}$The fact that the returns are so skewed across the portfolio is prima facie evidence that the (quite knowledgeable) investors cannot distinguish in advance the next Google from the other cases.

A second example provides more systematic evidence on the difficulty of predicting outcomes, even conditional on a venture capital firm making an investment. For a single large and successful venture capital firm that has invested more than $\$ 1$ billion over the last decade, we have access to both the outcomes of individual investments and the scores that partners assigned to each venture at the time of their first investment. We place the investments of this firm into buckets according

\footnotetext{
${ }^{2}$ Gompers and Lerner (2004) and Da Rin, Hellman, and Puri (2013) provide a comprehensive overview of these intermediaries. Chemmanur, Krishnan, and Nandy (2011) and Puri and Zarutskie (2012) provide recent evidence on the performance of venture-capital-backed startups. Parker (2004) provides a broader review of the literature on entrepreneurship.

${ }^{3}$ Total gross returns need to be estimated due to the fact that a venture's value at exit is missing for a large number of acquisitions, for firms that went bankrupt, and for the "living dead"-firms that are coded as still private but have not received follow-on financing for several years. Our research suggests that most of the acquisitions without data are fire sales and that firms that are coded as "alive" but have not received a follow-on round of financing within three years of the last financing are likely to be bankrupt. In the calculation reported above, we have conservatively assumed that unreported acquisitions were undertaken at 1.5 times cost and that firms that did not receive subsequent rounds of financing for three years, but were coded as still private, were liquidated at 0.25 times cost. The results are robust to assuming a wide range of possible values for these outcomes, including an (implausible) average of two times the dollars invested in the firm. These numbers correspond closely with numbers from Sahlman (2010) who uses data from eleven early-stage venture capital firms to show that 64 percent of their investments were terminated at a loss, while 8 percent of the investments, those that returned over five times the investment, generated about 60 percent of the gross return of the portfolio.
} 


\section{Figure 1}

\section{Total Cost and Total Return for a Venture Capital Firm}

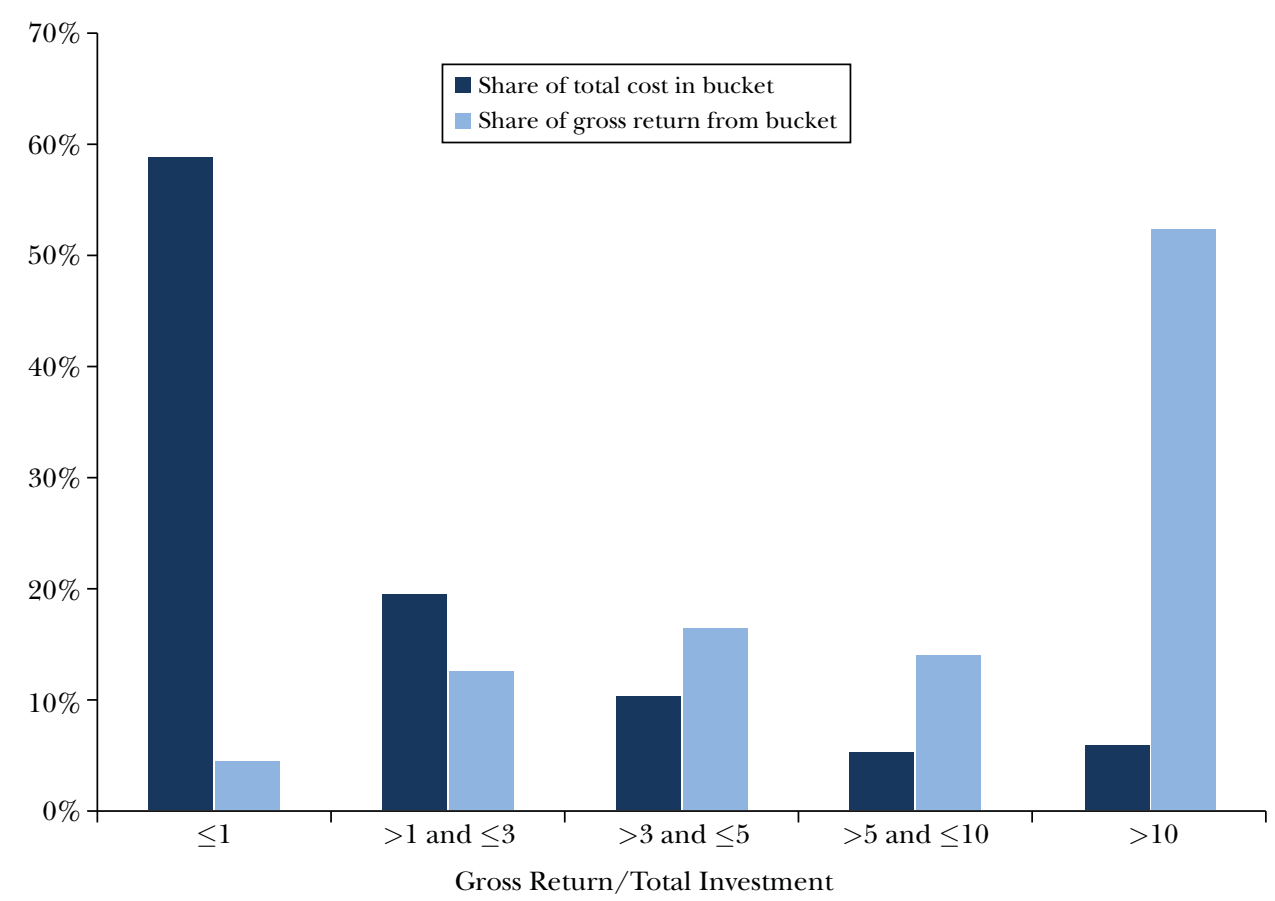

Source: Authors using proprietary data from an anonymous venture capital firm that has invested more than $\$ 1$ billion over the last decade.

Notes: Investments are placed into buckets according to their return multiple. For each bucket, we show the total cost and total return for that group of investments.

to their return multiples, and in Figure 1, show the total cost and total return for each bucket of investments. The distribution of outcomes for this firm follows the same pattern as the aggregate data on venture capital (with about 60 percent of investments terminated at a loss and 10 percent generating a return more than five times the capital invested).

The firm has an excellent track record in the industry, which implies a wellfunctioning algorithm for choosing and managing investments. Conditional on making an investment, however, Figures $2 \mathrm{~A}$ and $2 \mathrm{~B}$ show the limited ability of the venture capital investors to tell the most successful investments from the less successful ones-even for these experienced investors. Figure 2A highlights that the distribution of scores assigned to investments that ended up performing extremely well is statistically no different from the distribution of scores assigned to investments that ultimately failed or had mediocre returns..$^{4}$ (The labels on the horizontal axis

\footnotetext{
${ }^{4}$ The Kolmogorov-Smirnov test for equality of distribution functions could not reject the hypothesis that these were the same.
} 
Figure 2

\section{Scores Assigned to Investments at Time of First Investment and the Ultimate Returns of Those Investments, for One Venture Capital Firm}

A: Distribution of Scores by Outcome

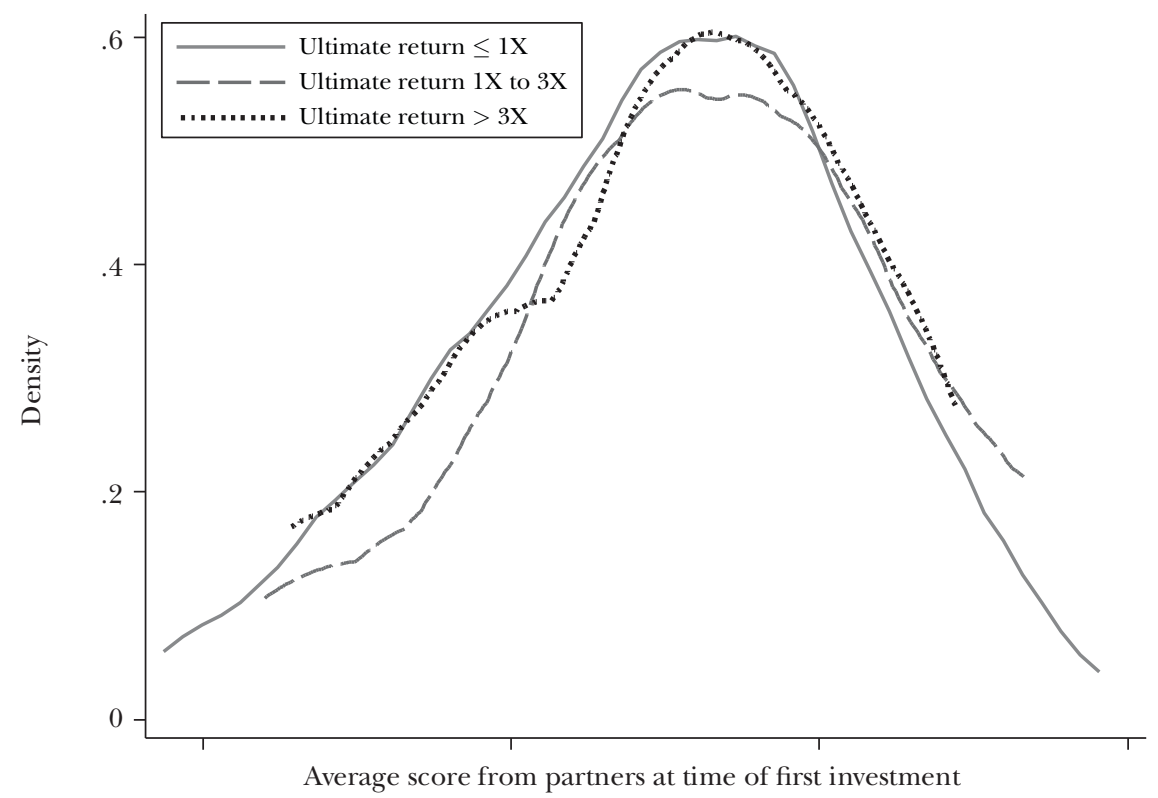

B: Correlation between Scores and Outcomes

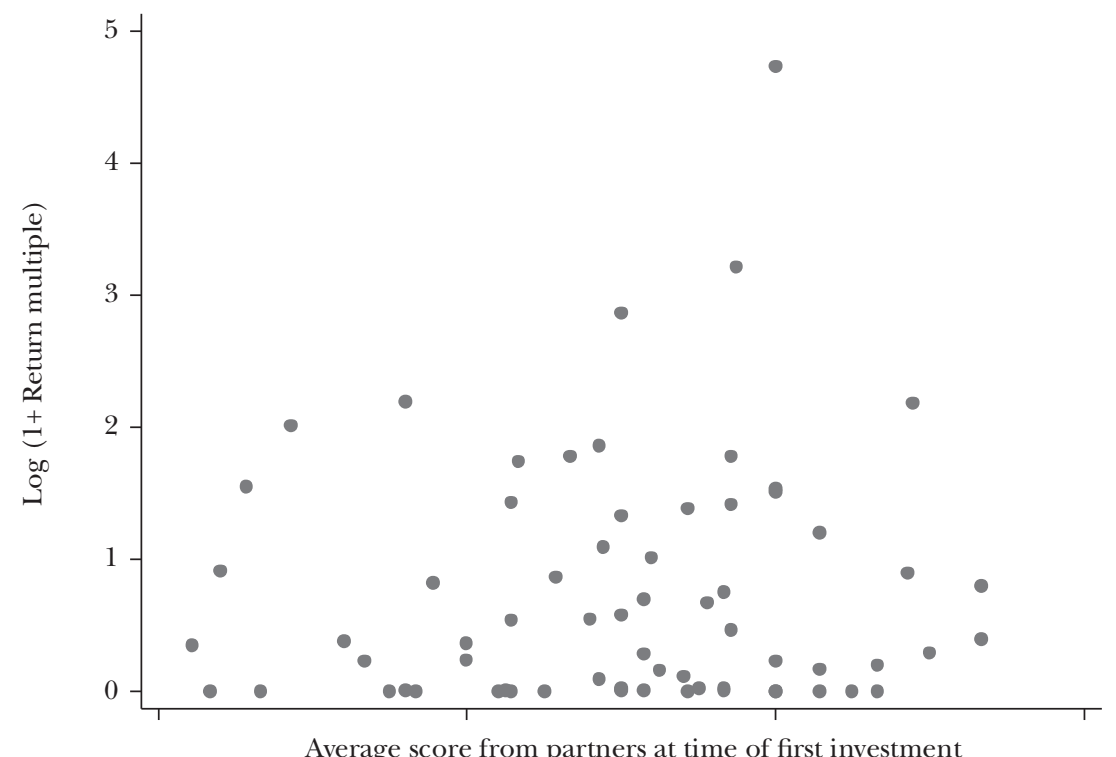

Note: The labels on the horizontal axis have been suppressed to maintain the confidentiality of the investor's rating scale, but lower predictions were on the left and higher predictions were on the right. 
have been suppressed to maintain the confidentiality of the investor's rating scale, but lower predictions were on the left and higher predictions were on the right.) Figure 2B is a scatterplot showing, for each of the firm's investments, the average score assigned at the time of first investment on the $\mathrm{x}$-axis versus a function of the return multiple on the y-axis. The raw correlation between scores and the return multiple from the investments is 0.1 .

This example shows that even conditional on making an investment, it is hard for the investors to predict which firm will be successful. Using a similar framework from a sample of early-stage "angel investors" in Kerr, Lerner, and Schoar (2014), the correlation among the interest levels assigned to funded deals and their ultimate success is less than 0.1. Again, these examples help illustrate the high degree of uncertainty present in these investments.

Thus, venture capital firms need to experiment, and many aspects of their business model facilitate or emphasize this experimentation. One example is their focus on sectors that are capital-efficient for both experimentation and subsequent scaling and that can generate large returns for the successful investments in a short period of time. Under these conditions, most notably associated with information technology investments, venture capital firms can run initial experiments of manageable financial sizes and then fund the winners to completion. The corollary to this, which is further elaborated upon below, is that venture capital activity is concentrated in a narrow range of technological opportunities. Some sectors, like renewable energy production, need to be proven at large scale to demonstrate technical feasibility and unit economics. Commercializing such ventures requires building large manufacturing plants and hence is significantly more capital intensive, and takes much longer. Following a brief period where venture capitalists invested heavily in biofuel and solar technologies only to learn these lessons the hard way, they have largely shied away from funding renewable energy production startups, instead devoting their attention within clean energy to startups commercializing energy efficiency, smart grid, and other software technologies (Nanda, Younge, and Fleming, forthcoming). Fleming (2001) and Fleming and Sorenson (2004) discuss the aggregate implications of a narrower range of search or recombination.

In addition to focusing on specific sectors, venture capital structures and contractual choices also address experimental challenges. For example, in a way that is similar to our earlier numerical example, venture capital investors provide staged financing to startup companies that tie each financial infusion to milestones-points at which information is revealed about the quality of the project. This structured financing builds real options (for example, Gompers 1995; Bergemann and Hege 2005; Bergemann, Hege, and Peng 2008), by matching the amount of money raised in each round to the specific uncertainty that needs to be resolved with that round of funding: for example, proof that the technology works, that consumers will buy the product, and so on. The most successful investors and entrepreneurs are able to identify the most important uncertainties facing a new idea and experiment in a way that resolves the greatest proportion of the uncertainty around them effectively and quickly. 
The consequence of this staging approach is that an important role of venture capital firms is to shut down ventures for which they are receiving bad signals. Investors exercise the abandonment options in several ways. Across financing rounds, the investors can choose to not reinvest in the company; within each financing round, venture capital firms also structure contracts to provide them with control and cash flow rights. Control rights allow venture capital firms to replace underperforming chief executive officers, and the investors can also push the company to reposition itself if the chosen path turns sour. These rights appear to be exercised often (for example, Hellman and Puri 2000; Kaplan, Sensoy, and Strömberg 2009; Tian 2011). 5

The available evidence suggests that this process of venture capital experimentation does lead to successful economic outcomes. Kortum and Lerner (2000) and Samila and Sorenson (2011) document spillover effects from venture capital activity within industries and cities, respectively. Using Census Bureau data, we provide descriptive evidence of how this sort of experimentation is associated with outcomes for ventures. We use name and address matching to identify new entrants that received venture capital investments during the 1986-1997 period. Looking ahead to 2007,75 percent of these venture-capital-backed ventures have shut down, but the remaining firms have grown to a level where they combine to equal 364 percent of the total employment of the original investments (including those that failed). For comparison, we generated a second sample of non-venture-capital-backed entrants that have the same four-digit industry, year, and starting employment level as the investment sample. In 2007, a greater share of this second group remains alive-only 66 percent have shut down. However, those that are alive only account for two-thirds (67 percent) of the total employment of their original sample. These matched ventures have thus grown, but not nearly to the extent of the venture-capital-backed group. While our simple matching procedure may leave residual differences across the groups and also does not account for either the role of selection or the effect of venture capital on startups' outcomes, it should not obscure the broad overall point: the venture-capital-backed ventures experienced a higher if similar rate of failure (75 versus 66 percent) but also experienced far greater employment gains (364 versus 67 percent of employment in their samples). High-growth ventures typically constitute a small proportion of new startups but are responsible for a disproportionate share of employment and GDP. As a rough benchmark, about 1,000 of the over 500,000 firms founded each year in the United States obtain venture capital finance, but these firms account for about 40 percent of new US publicly-listed companies over the last three decades (Ritter 2014).

\footnotetext{
${ }^{5}$ Many other aspects of the venture capital model reflect these cash-flow and control rights (for example, Kaplan and Strömberg 2003, 2004). One prominent example is convertible preferred stock that protects venture capital firms in bad outcomes by allowing them to redeem the full value of their investment, thereby treating the investment as debt to the extent that the failed venture has any residual value. On the other hand, in positive outcomes, the venture capital firm can choose to convert the preferred to common stock, allowing them to share in the upside when things go well.
} 


\section{Frictions for the Process of Experimentation-Costs of Experiments}

The costs of running experiments play a big role in entrepreneurship. Technological change in the last decade has dramatically lowered these costs, particularly in industries that have benefited from the emergence of the Internet, including trends like open-source software and cloud computing. Industry observers suggest that firms in these sectors that would have cost $\$ 5$ million to set up a decade ago can be done for under $\$ 50,000$ today. For example, open-source software lowers the costs associated with hiring programmers. In addition, fixed investments in high-quality infrastructure, servers, and other hardware are no longer necessary at the birth of many software firms because they can be rented in tiny increments from cloud computing providers and efficiently scaled up as demand for their products increases (Blacharski 2013; Palmer 2012). This reduced entry barrier has led to an explosion of experimentation with new entrepreneurial ideas in this area. Funding sources have also proliferated as the ability to finance these smaller and cheaper experiments is possible for individuals and groups beyond the traditional venture capital investors with large pools of capital.

One prominent example of this shift is the Lean Startup methodology advocated by serial entrepreneur Steve Blank and popularized by Eric Ries's (2011) book, "The Lean Startup." Many startup founders have shaped their efforts using the Lean Startup approach, and the ideas have reached the leadership of large companies like Jeff Immelt, the chief executive officer of General Electric. The core of the management style is a focus on identifying and developing "minimal viable products" (MVPs) that reveal how well the overall opportunity will fare. An example of an MVP is the release of a consumer website that has only 10 percent of the functionality that the founders ultimately envision for the product. However, by quickly building a workable version with only the bare essentials, the MVP approach seeks to validate as many assumptions as possible about the viability of the final product before expending enormous effort and financial resources. From the information collected during these experiments, the venture adjusts its course in a way that may involve pivoting from the original agenda. The followers of this methodology frequently discuss how to make their experiments ever more cost-effective, in large part so that they do not need to raise as much money to pursue a range of possible ideas.

This approach to building companies has coincided with the rapid rise of angel investors and crowd-funding platforms, ${ }^{6}$ particularly for consumer Internet startups.

\footnotetext{
${ }^{6}$ Angel investors are defined as individuals investing their own capital in startup ventures. Given the decentralized nature of such investments, it is extremely difficult to accurately quantify the size of the market. The Angel Capital Association (2012) estimates that its membership consists of about 8,000 accredited investors (who are individuals allowed by the Securities and Exchange Commission to make investments in risky, private startups) who invest in approximately 800 companies per year. The size of the broader angel market has been estimated to be as large as $\$ 20$ billion dollars, but the vast majority of this is tiny investments made by individuals in firms that are already cash-flow positive (Shane 2009). The total does, however, provide a sense of how large the crowd-funding market could be given recent changes in regulation through the Jumpstart Our Business Startups (JOBS) Act of 2012, which allow a larger number of individuals to invest legally in private companies (Nanda and Kind 2013).
} 
For example, AngelList, a platform dedicated to matching startups with angel investors experienced rapid growth since its founding in 2007, and in June 2013 had approximately 100,000 startups and 18,000 accredited investors on its platform, of which 2,000 had been funded (Nanda and Kind 2013). The lower costs associated with initial experiments implies that those with pools of capital smaller than typical venture capitalists can more easily become involved in these financing decisions. Because positive information from experiments leads the valuation of startups in subsequent rounds to increase substantially, this leads to less dilution for early-stage financiers and makes it even more attractive for investors with smaller pools of capital to get involved with financing decisions. Equally important, however, is the fact that as these experiments get better at quickly telling apart projects with high and low potential, they allow startups that would probably not have received funding in the past due to their uncertain outcomes to now receive financing. Ewens, Nanda, and Rhodes-Kropf (2014) show that these are particularly likely to be startups that had a very small chance of being extremely successful, such as those founded by young, inexperienced, first-time entrepreneurs. While these individuals would not have received capital in the past, the financing environment has changed in recent years, creating room for cohort-based accelerator programs with an educational component, such as Y-Combinator, that aim to provide mentoring, networks, and capital to such founders (Graham 2008). Fehder and Hochberg (2014) document that there were no such programs in the United States in 2004, but by 2013 over 40 such accelerators were functioning across the United States.

While a trend toward lower start-up costs is particularly true in software and information technology businesses, where the cost of experimentation has declined dramatically and the frequency with which one learns new information about the product is very high, the same forces exist in very capital-intensive industries as well. An example is Terrapower, a startup trying to commercialize a new way of producing nuclear energy (Sahlman, Nanda, Lassiter, and McQuade 2012). Bill Gates, an early backer of Terrapower, noted that rapid advances in computing power provide this startup with significant advances toward experimentation. In the past, Terrapower would have had to construct an entire nuclear power plant to test whether its new technology would work in practice, costing several billion dollars and taking years to complete, making it impossible to finance in the first place. Now, with the introduction of supercomputers, Terrapower's engineers can simulate the inside of a nuclear reactor, learn whether its technology will work, and make rapid (and much cheaper) iterations to gain more confidence about the potential of the technology before ever constructing the physical nuclear power plant. This in turn makes it viable to finance an initial exploration for an early-stage investor.

These examples reinforce two points about the cost of experimentation. First, differences across industries in the ability and cost to learn about the final outcome have a huge bearing on the degree of experimentation that we see in early stagesthe very long time frames and costs for learning about potential technologies in renewable energy or different approaches to curing cancer create a dearth of experimentation, despite intense societal interest (Fernandez, Stein, and Lo 2012). Even 
for venture capital firms, the levels of investment required for clean energy efforts or certain healthcare investments tend to be too high per project for them to bear.

Second, the pace of technological progress has a feedback effect on new innovations. As technological advances such as supercomputers or cloud computing diffuse, they affect the cost of experimentation in completely different sectors like nuclear energy and consumer Internet. The advances mean that projects that had a negative expected value in the past become viable. Referring to our earlier numerical example, they may drop the cost of the hypothetical test from several hundred dollars to less than $\$ 89$. This spillover effect helps sustain and potentially even increase high rates of technological progress.

\section{Frictions for the Process of Experimentation-Organizational}

A key part of experimentation is the ability to terminate projects, but organizations differ in their ability and willingness to terminate underperforming ventures. The venture capital industry has long used the expression "throwing good money after bad money" to warn against continual investment in startups for whom the initial experiments reveal poor information. Venture capital firms that shut down more ventures do not necessarily perform worse, and, in fact, some of the best venture capital firms have among the highest rates of abandoning projects-in part because their skill at designing experiments and acting upon the results allows them to pursue more aggressive strategies and enter into more uncertain domains.]

This capacity to terminate projects, while certainly not exclusive to the venture capital community, is often difficult to replicate within large corporations or through equity markets. Large corporations, for example, often find it difficult to terminate experiments that aren't working out, due in part to career concerns of the managers in charge of the effort, the "soft budget constraints" that arise when a large corporation can keep providing funding for a time, and similar traits. The initial experiment may also provide ambiguous or slightly negative information that can be interpreted in different ways depending upon the biases of parties. In several ways, the venture capital system is designed to counteract these tendencies, beginning with an industry structure where venture capital firms are separate from the startup itself but still capable of intensive monitoring. Another mechanism often used by venture capital firms is to bring in new investors with each financing round to ensure that the deal is evaluated by outsiders. In academia, the academic tenure process that includes external review after a specific time horizon generates comparable features.

Of course, because venture capital investors consider each investment as contributing to overall portfolio returns, their incentives are not always aligned with entrepreneurs in terms of strategic decisions such as when to shut down or exit

\footnotetext{
${ }^{7}$ While the higher rate of abandoning projects does not jump out from the statistics we provided above, it is worth noting that venture capital investors also likely select better projects, so that a simple comparison of realized failure rates does not provide a complete picture of how much more they abandon projects compared to non-venture-capital-backed firms.
} 
an investment. For example, Gompers (1996) has documented the incentives of venture capital firms to engage in grandstanding (taking companies public earlier than may be optimal) to develop a reputation that enables them to raise follow-on funds. Venture capital investors may also choose to shut down an underperforming firm if it is unlikely to generate high gross returns, or they may continue to reinvest if they want to build a reputation as entrepreneur-friendly. These decisions may not always be optimal for the firm.

These examples highlight a related tension with organizational design, however. Innovation requires running experiments that will often fail, and such failures will occur even if the idea looked promising at the start and all parties acted in good faith. These features may require an organizational tolerance for failure in the short-term, with compensation rewards over the long-run based upon success (Manso 2011). This tolerance allows opportunities for early experimentation to identify the best course of action, while the long-term compensation tied to performance combats the "moral hazard" concern that decision makers might take excessive risks, and it solicits their best efforts.

How organizations balance the termination of poor experiments with maintaining a tolerance for failure in turn affects the overall set of projects that they choose to start. Nanda and Rhodes-Kropf (2012) show that the inability or the unwillingness to terminate projects when intermediate information is negative leads organizations to start projects that are less experimental in the first place. In other words, organizations can pick a radical range of projects at the start and terminate a high percentage of them, or pick a more limited range of projects at the start and terminate fewer of them. Large bureaucratic organizations often struggle with terminating projects, and these differences provide a rationale for why large companies are comparatively better at pursuing incremental improvements than radical innovations, although this is of course not true in every case. March (1991) and Akcigit and Kerr (2010) provide greater discussion on firm sizes and exploration versus exploitation choices. Lerner (2012) provides a discussion of the relative benefits of the traditional model of research and development within firms versus the model of venture capital investors, and Thomke (2003) discusses how large companies can take insights from the model of experimentation to improve the way in which they develop and advance innovations.

\section{Frictions for the Process of Experimentation-Continuation and Financing Risk}

Successful experimentation requires being able to capitalize on experiments that reveal positive outcomes, and these upside scenarios can be as tricky as termination decisions. Financing projects in stages requires that startups return to the capital markets at regular intervals for more capital. Thus far, we have emphasized positive aspects of multiple financing rounds (for example, the advantages of having an outside investor not previously involved with the company value the venture). A negative aspect is that entrepreneurs and early-stage investors feel vulnerable to the state of the financial markets at each round of financing. At times, financial capital is freely available, while in other instances it may be hard to come by, even 
for otherwise sound projects. These financing constraints can be marketwide or they can be specific to sectors due to the degree to which investors herd around certain hot sectors.

Venture capital investors routinely refer to "financing risk" (similar to rollover risk) to describe how otherwise sound projects may not obtain capital for the next experiment. One way to protect against financing risk is to go less frequently to the capital markets, by taking larger chunks of money at each stage. This, however, reduces the value of the abandonment options for venture capital firms. Nanda and Rhodes-Kropf $(2010,2013)$ argue that hot markets-times when financing risk is low-allow projects with the highest real option values to be funded, because the continuation risk is lower for all projects in the economy. Empirically, venture-capital-backed firms that are first funded during hot markets have the highest failure rates, but conditional on being successful, startups funded in more-active periods were valued higher at initial public stock offering or acquisition compared to startups funded in less-active periods exiting at the same time. Financing risk is most salient for projects that need to go back to the capital markets many times, and thus projects that are worst hit by this risk are experimental new technologies that tend to have the highest option value. In fact, a possible implication of this work, which is related to work on the role of stock markets in financing innovation (Brown, Fazzari, and Petersen 2009), is that the most innovative projects in the economy may need times of low financing risk ("hot financial markets") to drive their initial commercialization.

Financing risk is representative of a broader class of continuation features that govern the degree to which experimentation can be pursued. To illustrate, consider some of the differences between clean energy and biotech; biotech also requires substantial investment and very long horizons but is the beneficiary of substantially more venture capital investment. Biotech startups and the pharmaceutical industry are part of a vibrant "market for ideas" (Gans, Hsu, and Stern 2002) that allows biotech companies to sell the results of their experiments at milestones. That is, a biotech company can undertake a first experiment to show that a project that originally seemed to have had a 0.1 percent chance of becoming a blockbuster drug has in fact a 5 percent chance. This experiment has generated substantial information value, and pharmaceutical companies are willing to buy the remaining 1-in-20 opportunity for their drug development portfolios. This market works because the science used in the first experiment is observable and verifiable, a patent system protects the startup from intellectual theft, and the long-term opportunity is more protected compared to clean energy innovations (which can face competition from all alternative sources of energy, including the opening up of strategic oil reserves). Such a "market for ideas" is much less developed for clean energy, and as a consequence entrepreneurs and investors who are considering an experiment in this area face additional continuation risks (Nanda, Younge, and Fleming, forthcoming). Relatedly, competition to acquire new technologies among pharmaceutical firms combined with a relatively robust market for initial public offerings have meant that the upside from biotechnology innovation, if successful, is sufficiently high to warrant the financing of upstream 
experimentation. We return to the role of the markets for initial public offerings in greater detail in the next section.

\section{Discrete Choices and Individuals-A Process of Experimentation}

We close this section by emphasizing its most prominent feature-the role of humans, often just a few humans, in making these decisions. Economic models often focus on the fact that in well-functioning economies, good ideas are rewarded and flourish relative to worse ideas. But they are silent on how these ideas emerge.

A central theme of this section is that entrepreneurs and investors must make discrete choices, often with quite incomplete information and uncertainty about the future, about which ideas to progress and which to shut down. Financiers rather than markets dictate which projects are realized, as they choose which experiments to attempt, how to interpret the results, and whether to continue or abandon the investment. The entrepreneurial landscape at the micro-level is thus characterized by individuals choosing the fate of a venture based on what they have learned about what is likely to work before it competes in the product market.

This section has emphasized how constraints on the ability of investors to experiment efficiently can shape which industries, organizations, and time periods see the most radical innovations. It also sets the framework for understanding where barriers to experimentation may lead to market failures. For example, intermediate experiments may reveal very little about the ultimate success of some projects (such as building a particle collider or the nuclear power startup before the advent of simulation), requiring extremely large investments before one can learn about their viability. Alternatively, the horizon for commercialization may be extremely uncertain and distant, such as in the case of research in basic science. Institutional regimes such as academia (and at times the government) may thus be critical to enable experimentation in areas that are of importance to society but where a process of serial experimentation by profit-seeking investors is unlikely to provide a set of stepping-stones to the technologies behind disruptive innovation.

\section{Economic Experiments at the Society Level}

While we have focused our attention on the difficulty in predicting outcomes for new technologies, many of these challenges also exist for firms in the broader economy. For example, Shane (2009) documents that of the approximately 500,000 startups that were founded in the United States in 1996, over half had failed by 2002 and only about 3,500 achieved sales of greater than $\$ 10$ million. Haltiwanger, Jarmin, and Miranda (2013) note the difficulty in predicting upfront which firms will succeed even among producers of homogeneous goods such as cement. The laws and institutions at the regional and national level can therefore play a critical role in driving productivity growth-often through the incentives they create or the costs that they impose on the ability to effectively experiment. For example, Glaeser, Kerr, and Kerr (forthcoming) trace the effects of entrepreneurship on long-run 
urban growth by documenting how cities with industrial and mining legacies in 1900 found it harder to create the up-or-out dynamic associated with productivity growth. They argue that the institutions (industrial structure, culture, and skill base) created by the predominantly large mining firms in the 1900s hindered entrepreneurship in the modern era, leading to systematically lower urban growth in these regions post-1970.

Although some institutions are extremely persistent and hard to change, we outline some types of policies that seem to be particularly effective in promoting "economic experiments" in the form of entrepreneurship.

\section{Democratizing Entry and Facilitating Efficient Failure}

Bank finance and debt financing more generally is an extremely important source of capital for young companies. The US Small Business Administration has estimated that there were 21 million small business commercial and industrial loans outstanding in 2010 (defined as loans being below $\$ 1$ million) that were valued at $\$ 310$ billion (Office of Advocacy, US SBA 2013). While many small businesses are not young, Robb and Robinson (2014) document that debt finance is important even among young firms. They look at the sample of startups in the Kauffman Firm Survey and find that within the first three years of founding, 40 percent of the funding source for these startups is constituted by outside debt, over and above the 4 percent of debt that consists of the owner's credit cards and personal loans.

Changes in the availability and terms of bank finance can therefore have important implications for entrepreneurship. For example, Kerr and Nanda (2009) consider how the banking competition fostered by the state-level US banking deregulations that occurred from the 1970s through the 1990s affected entrepreneurship and the economy. These deregulations facilitated greater competition by allowing out-of-state banks to enter local markets, thereby increasing access to credit and lowering the cost of external finance. Using micro-level data from the US Census Bureau, Kerr and Nanda (2009) find evidence for the standard story of creative destruction- $\mathrm{a}$ few strong entrants challenging and later replacing incumbent firms. However, the mechanism through which this was achieved was through widespread entry that largely resulted in failure, so that the most pronounced impact was a massive increase in churning among new entrants..$^{8}$ Similarly, Chava, Oettle, Subramanian, and Subramanian (2013) examine innovation outcomes following the banking deregulations and find that banking deregulation facilitated greater risk taking and experimentation by small firms. Because it is hard to know beforehand which projects are going to be successful, "democratizing entry" seems to be an important trait of well-functioning capital markets.

Efficient experimentation implies that institutional environments facilitating exit are as important as those that facilitate entry. Two areas that have received

\footnotetext{
${ }^{8}$ Prior work by Black and Strahan (2002) and Cetorelli and Strahan (2006) connected the deregulations to higher entry rates, but it was quite puzzling that the elasticity for entrepreneurship was about ten times higher than the response observed on any other dimension like productivity change.
} 
significant attention in recent years are the role of bankruptcy law and employment protection laws and tradeoffs involved as they relate to experimentation.

On the one hand, bankruptcy laws that favor creditors allow them to recoup as much capital as they can from the startup-encouraging them to lend in the first place (Berkowitz and White 2004; Cumming forthcoming; Cerqueiro, Hegde, Penas, and Seamans 2013). Such laws also discourage the moral hazard that might otherwise arise among entrepreneurial agents if they faced little need to repay creditors. On the other hand, entrepreneurial failure allows society to test uncertain projects. This process requires separating the entrepreneur from the firm, as is accomplished to some extent by the limited liability provision that entrepreneurs are not personally liable for the debts of a firm, and thus provides entrepreneurs with the ability to terminate projects and move on. As an example, Eberhart, Eesley, and Eisenhardt (2013) find that a bankruptcy reform in Japan that reduced the consequences of closing a firm encouraged greater levels of entrepreneurship and risk taking following the reform. The best policy appears to involve striking a balance between a good measure of limited liability for entrepreneurs, allowing them to transition across projects without severe and lasting penalties, along with some protections or restrictions for small or unsophisticated investors who may not comprehend fully the low likelihood of the entrepreneur's success. While legal factors play a role in reducing the downside from failure, cultural factors such as a stigma of failure can also play a role in hindering entry. In some regions, such as Silicon Valley, past failure can even be seen as a badge of honor, making it much easier for individuals to take big risks in terms of startup ventures.

A related set of issues can arise from strict employment protection laws that limit the ability of firms to adjust their workforce rapidly and in that way act as an effective tax on employment adjustments (Autor, Kerr, and Kugler 2007). Many ultimately successful startups have had to undertake one or more critical changes in their business model, which in turn require substantial adjustments in their workforce. One of the tradeoffs of legal mandates for employment is that they make it much more difficult for high-growth startups to experiment and for innovative, volatile sectors to form (for example, Saint-Paul 2002; Samaniego 2006). Indeed, venture capital investment is lower in countries with stringent employment protection laws, and the more-volatile sectors are the most affected (Bozkaya and Kerr forthcoming). In this sense, the flexibility of labor markets governs the types of projects that entrepreneurs can undertake (Fallick, Fleischman, and Rebitzer 2006).

\section{Appropriating Value in Successful States of the World}

Beyond the policies that shape an entrepreneur's ability to experiment when things are going poorly, policies or conditions that limit the value that entrepreneurs or investors receive in good states of the world are also important. Some conditions like the extent of patent protection were noted earlier in our comparison of biotech and clean energy investments. More generally, the investors and state-contingent financial contracts that we describe require strong property rights 
and a sound rule of law (for example, La Porta, Lopez-de-Silanes, Shleifer, and Vishny 1997). Similarly, public equity markets are critical to rewarding startups that are successful, by allowing investors and entrepreneurs to cash out on the expectation of future growth. When equity markets do not work well or there are limited opportunities to exit and retrieve at least a portion of the earlier investment, it becomes much harder to experiment (for example, Black and Gilson 1998; Michelacci and Suarez 2004).

\section{Policy Implications}

How should policymakers interested in promoting entrepreneurship think about the role of experimentation? Clearly, difficult entry regulations suppress the experimentation undertaken by startups (Klapper, Laeven, and Rajan 2006) and often are difficult to justify on any grounds. As one example, Fairlee, Kapur, and Gates (2011) describe the extent to which the prevalence of employer-provided health insurance in the US economy serves as an implicit entry barrier for potential founders of new firms, making it more difficult for them to leave current jobs.

In addition, taking the experimental perspective seriously suggests that it is a poor idea for government to seek to pick and promote individual firms. After all, even the most-experienced venture capital firms have substantial success in only one of every ten investments they pick, so we shouldn't expect inexperienced and possibly not-very-objective politicians to do better. Indeed, one of the features that make market-based economies better at commercializing radical innovations is the decentralized and parallel nature with which new ideas are tested (Rosenberg 1994; Qian and Xu 1998; Scherer and Harhoff 2000). Politicians also have greater difficulty terminating projects-that is, telling taxpayers that legislative decisions have spent their money with little or no return. In our experience, most economists buy into this wariness of policymakers acting as a venture capital firm, and many go a step further and caution against picking an individual sector or industry to support. Virtually every state has a biotech initiative, but few will be successful. Lerner (2009) emphasizes the dismal performance of policies attempting to seed specific ventures or industries.

Governments are more likely to facilitate effective entrepreneurship if they work to reduce the costs of experimentation in general. What we have in mind here is not so much government programs that seek to target start-ups with particular benefits, but instead a careful consideration of the broader regulatory framework, including labor laws and requirements with which new entrants need to comply, with a focus on how they affect incentives for entry. These efforts to structure a better playing field are admittedly less glamorous than announcing a new biotech cluster initiative, but they are far more likely to have sustained effects.

As alluded to in the previous section, the experimentation view also suggests that there may be systematic market failures when the costs associated with experimentation are too high or the returns are too uncertain and far into the future. This creates a framework for thinking about which sectors, such as say basic science, may warrant sustained government support. 
Finally, government should be cautious about industrial policies that seek to minimize business failures, as such policies may only be propping up firms that need to fail. For example, Acemoglu, Akcigit, Bloom, and Kerr (2013) build a model of firm-level innovation, productivity growth, and reallocation featuring endogenous entry and exit, and calibrate it using firm-level micro data from the Census. Their results highlight a key role for new entrants in policies to promote innovation and growth. Acemoglu et al. (2013) find that while policies like research and development tax credits to entrants can help and may encourage growth, their impact pales in comparison to removing artificial support for inefficient incumbents.

\section{Conclusions}

Picking up a quotation originally made by Michael Jordan to describe missing basketball shots, a prominent venture capitalist, Vinod Khosla, emphasizes, "our willingness to fail gives us the ability and opportunity to succeed where others may fear to tread" (Khosla Ventures, no date; Khosla 2013). This paper has outlined our perspective on entrepreneurship that emphasizes this fundamental role for experimentation. Viewing entrepreneurship as experimentation allows individuals and societies to evaluate businesses and technologies in domains with greater uncertainty than otherwise possible, unlocking deep growth opportunities.

Economists should bear in mind two very different forms of experimentation that are associated with entrepreneurship. One form is the economic experimentation that takes place in market-based economies when several new ideas, products and technologies are continually tested and either displace existing technologies or more likely fail themselves. A second less-appreciated form of experimentation happens at the micro-level, before these ideas compete, and relates to the process of bringing new ideas to the market. There are too many opportunities to pursue with scarce resources, and the best-designed experiments can come back with misleading or ambiguous results. Under these conditions, specific choices made by discrete individuals-especially founders of firms and early-stage investorsbecome very important. Recent research in financial economics, organizational design, and related fields highlight how the costs associated with the ability of investors to experiment can alter the nature of entrepreneurship and help to explain why entrepreneurship is more prevalent in certain industries, regions, or periods of time.

Less than a decade ago, research on entrepreneurship within economics had little internal cohesion; instead, researchers working on entrepreneurship were spread out within broader fields like finance, labor economics, or macroeconomics. Today, while most researchers in this area continue to keep one foot firmly planted in a traditional field, the internal cohesion for entrepreneurial research has formed and is rapidly obtaining scale. Researchers on entrepreneurship are themselves experimenting with new ideas and new directions, and we expect this area of research to develop rapidly in the coming years. 
- We appreciate comments and editorial direction by David Autor, Chang-Tai Hsieh, and Timothy Taylor. The research in this paper was conducted while the authors were Special Sworn Status researchers of the US Census Bureau at the Boston Census Research Data Center (BRDC). Support for this research from the NSF grant ITR-0427889 [BRDC], the Division of Research and Faculty Development at Harvard Business School, and from the Kaufman Foundation is gratefully acknowledged. Research results and conclusions expressed are the authors and do not necessarily reflect the views of the Census Bureau or the NSF. This paper has used proprietary data from a venture capital firm that requests it remain anonymous, and it has screened the paper to ensure that no confidential data are revealed.

\section{References}

Acemoglu, Daron, Ufuk Akcigit, Nicholas Bloom, and William R. Kerr. 2013. "Innovation, Reallocation and Growth." NBER Working Paper 18993.

Akcigit, Ufuk, and William Kerr. 2010. "Growth through Heterogeneous Innovations.” NBER Working Paper 16443.

Angel Capital Association. 2012. "ACA, Angel Groups and Angel-Backed Companies." Slides, September. http://www.angelcapitalassociation .org/data/Documents/Resources/ACAandAngel GroupBackground09-12.pdf.

Autor, David H., William R. Kerr, and Adriana D. Kugler. 2007. "Does Employment Protection Reduce Productivity? Evidence from US States." Economic Journal 117(521): 189-217.

Bergemann, Dirk, and Ulrich Hege. 2005. "The Financing of Innovation: Learning and Stopping." RAND Journal of Economics 36(4): 719-52.

Bergemann, Dirk, Ulrich Hege, and Liang Peng. 2008. "Venture Capital and Sequential Investments." Working paper.

- Berkowitz, Jeremy, and Michelle J. White. 2004. "Bankruptcy and Small Firms' Access to Credit." Rand Journal of Economics 35(1): 69-84.

Bessemer Venture Partners. No date. "Antiportfolio." http://www.bvp.com/portfolio/anti portfolio.

Blacharski, Dan. 2013. "Top Ten Ways the Cloud
Has Changed How Startups Launch.” Techie.com, November, 26. http:/ / techie.com/top-ten-ways-the -cloud-has-changed-how-startups-launch/.

-Black, Bernard S., and Ronald J. Gilson. 1998. "Venture Capital and the Structure of Capital Markets: Banks versus Stock Markets." Journal of Financial Economics 47(3): 243-77.

-Black, Sandra E., and Philip E. Strahan. 2002. "Entrepreneurship and Bank Credit Availability." Journal of Finance 57(6): 2807-33.

Bozkaya, Ant, and William Kerr. Forthcoming. "Labor Regulations and European Venture Capital." Journal of Economics and Management Strategy.

Brown, James R., Steven M. Fazzari, and Bruce C. Petersen. 2009. "Financing Innovation and Growth: Cash Flow, External Equity and the 1990s R\&D Boom." Journal of Finance 64(1): $151-85$.

Cerqueiro, Geraldo, Deepak Hegde, María Fabiana Penas, and Robert Seamans. 2013. "Debtor Rights, Credit Supply, and Innovation." Unpublished paper.

Cetorelli, Nicola, and Philip Strahan. 2006. "Finance as a Barrier to Entry: Bank Competition and Industry Structure in Local U.S. Markets." Journal of Finance 61(1): 437-61.

Chava, Sudheer, Alexander Oettl, Ajay Subramanian, and Krishnamurthy Subramanian. 
2013. "Banking Deregulation and Innovation." Journal of Financial Economics 109(3): 759-74.

Chemmanur, Thomas J., Karthik Krishnan, and Debarshi K. Nandy. 2011. "How Does Venture Capital Financing Improve Efficiency in Private Firms? A Look beneath the Surface." Review of Financial Studies 24(12): 4037-90.

Cumming, Douglas. Forthcoming. "Measuring the Effect of Bankruptcy Laws on Entrepreneurship across Countries." Journal of Entrepreneurial Finance.

Da Rin, Marco, Thomas Hellmann, and Manju Puri. 2013. "A Survey of Venture Capital Research." Chap. 8 in Handbook of the Economics of Finance, Vol. 2, Part A, edited by George Constantinides, Milton Harris, and René M. Stulz. Amsterdam: North Holland.

Dosi, Giovanni, and Richard R. Nelson. 2010. "Technical Change and Industrial Dynamics as Evolutionary Processes." In Handbook of the Economics of Innovation, Vol. 1 edited by B. H. Hall and N. Rosenberg, 51-127. Amsterdam: North Holland.

Eberhart, Robert, Charles E. Eesley, and Kathleen M. Eisenhardt. 2013. "Failure is an Option: Failure Barriers and New Firm Performance." Stanford University Working Paper 111.

Ewens, Michael, Ramana Nanda, and Matthew Rhodes-Kropf. 2014. "Entrepreneurship and the Cost of Experimentation." Unpublished paper.

Fairlee, Robert W., Kanika Kapur, and Susan Gates. 2011. "Is Employer-based Health Insurance a Barrier to Entrepreneurship?" Journal of Health Economics 30(1): 146-62.

Fallick, Bruce, Charles A. Fleischman, and James Rebitzer. 2006. "Job-hopping in Silicon Valley: Some Evidence Concerning the Microfoundations of a High-Technology Cluster." Review of Economics and Statistics 88(3): 472-81.

Fehder, Daniel C., and Yael V. Hochberg. 2014. "Accelerators and the Regional Supply of Venture Capital Investment." Unpublished paper.

Fernandez, Jose-Maria, Roger M. Stein, and Andrew W. Lo. 2012. "Commercializing Biomedical Research through Securitization Techniques." Nature Biotechnology 30(10): 964-75.

Fleming, Lee. 2001. "Recombinant Uncertainty in Technological Search." Management Science 47(1): 117-32.

-Fleming, Lee, and Olav Sorenson. 2004. "Science as a Map in Technological Search." Strategic Management Journal 25(5-9): 909-28.

Gans, Joshua, David H. Hsu, and Scott Stern. 2002. "When Does Start-up Innovation Spur the Gale of Creative Destruction?" RAND Journal of Economics 33(4): 571-86.

Glaeser, Edward L., Sari Pekkala Kerr, and William R. Kerr. Forthcoming. "Entrepreneurship and Urban Growth: An Empirical Assessment with Historical Mines." Review of Economics and Statistics.

Gompers, Paul A. 1995. "Optimal Investment, Monitoring, and the Staging of Venture Capital." Journal of Finance 50(5): 1461-89.

Gompers, Paul A. 1996. "Grandstanding in the Venture Capital Industry." Journal of Financial Economics 42(1): 133-56.

Gompers, Paul, and Josh Lerner. 2004. The Venture Capital Cycle. Cambridge, MA: MIT Press.

Graham, Paul. 2008. "A New Venture Animal." March, http://paulgraham.com /ycombinator.html.

Grenadier, Steven R., and Andrey Malenko. 2011. "Real Options Signaling Games with Applications to Corporate Finance." Review of Financial Studies 24(12): 3993-4036.

Hall, Robert E., and Susan E. Woodward. 2010. "The Burden of the Nondiversifiable Risk of Entrepreneurship." American Economic Review 100(3): 1163-94.

-Haltiwanger, John, Ron S. Jarmin, and Javier Miranda. 2013. "Who Creates Jobs? Small versus Large versus Young." Review of Economics and Statistics 95(2): 347-61.

Hayek, Friedrich A. 1948. Individualism and Economic Order. University of Chicago Press.

-Hellmann, Thomas, and Manju Puri. 2000. "The Interaction between Product Market and Financing Strategy: The Role of Venture Capital." Review of Financial Studies 13(4): 959-84.

Kaplan, Steven N., Berk A. Sensoy, and Per Strömberg. 2009. "Should Investors Bet on the Jockey or the Horse? Evidence from the Evolution of Firms from Early Business Plans to Public Companies." Journal of Finance 64(1): 75-115.

Kaplan, Steven N., and Per Strömberg. 2003. "Financial Contracting Theory Meets the Real World: An Empirical Analysis of Venture Capital." Review of Economic Studies 70(2): 281-315.

Kaplan, Steven N., and Per Strömberg. 2004. "Characteristics, Contracts, and Actions: Evidence from Venture Capitalist Analyses." Journal of Finance 59(5): 2177-2210.

Kerr, William R., Josh Lerner, and Antoinette Schoar. 2014. "The Consequences of Entrepreneurial Finance: Evidence from Angel Financings." Review of Financial Studies 27(1): 20-55.

Kerr, William R., and Ramana Nanda. 2009. "Democratizing Entry: Banking Deregulations, Financing Constraints, and Entrepreneurship." Journal of Financial Economics 94(1): 124-49.

Klapper, Leora F., Luc Laeven, and Raghuram G. Rajan. 2006. "Entry Regulation as a Barrier to Entrepreneurship." Journal of Financial Economics 82(3): 591-625. 
Knight, Frank H. 1921. Risk, Uncertainty, and Profit. Boston, MA: Houghton Mifflin.

Kortum, Samuel S., and Josh Lerner. 2000. "Assessing the Contribution of Venture Capital to Innovation." RAND Journal of Economics 31(4): 674-92.

Khosla Ventures. No date. Company website mainpage, http://www.khoslaventures.com/ (accessed 5/14/14).

Khosla, Vinod. 2013. "Fail as Often as You Want, And Fail Well." Video of a speech posted March 10, 2013, at Wunderman Reports.com. http://www .wundermanreports.com/fail-as-often-as-you-want -and-fail-well.

Landier, Augustin. 2005. "Entrepreneurship and the Stigma of Failure." Unpublished paper.

- La Porta, Rafael, Florencio Lopez-de-Silanes, Andrei Shleifer, and Robert Vishny. 1997. "Legal Determinants of External Finance." Journal of Finance 52(3): 1131-50.

Lerner, Josh. 2009. Boulevard of Broken Dreams: Why Public Efforts to Boost Entrepreneurship and Venture Capital Have Failed-And What to Do about It. Princeton University Press.

Lerner, Josh. 2012. The Architecture of Innovation: The Economics of Creative Organizations. Boston, MA: Harvard Business School Press.

Levere, Jane L. 2013. "Airbnb Campaign Uses Birdhouses to Widen Its Reach." New York Times, December 15. http://www.nytimes .com/2013/12/16/business/media/airbnb -campaign-uses-birdhouses-to-widen-its-reach.html.

Manso, Gustavo. 2011. "Motivating Innovation." Journal of Finance 66(5): 1823-69.

- March, James G. 1991. "Exploration and Exploitation in Organizational Learning." Organizational Science 2(1): 71-87.

Michelacci, Claudio, and Javier Suarez. 2004. "Business Creation and the Stock Market." Review of Economic Studies 71(2): 459-81.

Nanda, Ramana, and Liz Kind. 2013. "AngelList." Harvard Business School Case 814-036.

Nanda, Ramana, and Matthew Rhodes-Kropf. 2010. "Financing Risk and Innovation." Harvard Business School Working Paper 11-013.

Nanda, Ramana, and Matthew Rhodes-Kropf. 2012. "Innovation and the Financial Guillotine." Harvard Business School Working Paper 13-038.

Nanda, Ramana, and Matthew Rhodes-Kropf.

2013. "Investment Cycles and Startup Innovation." Journal of Financial Economics 110(2): 403-18.

Nanda, Ramana, Ken Younge, and Lee Fleming. Forthcoming. "Innovation and Entrepreneurship in Renewable Energy." In The Changing Frontier: Rethinking Science and Innovation Policy edited by Adam Jaffe and Ben Jones. National Bureau of Economic Research.
Office of Advocacy, US Small Business Association. 2013. Small Business Lending in the United States 2012. http://www.sba.gov/sites/default /files/files/sbl_12study.pdf.

Palmer, Maija. 2012. "Cloud Computing Cuts Start-up Costs." Financial Times, February 29.

Parker, Simon C. 2004. "The Economics of SelfEmployment and Entrepreneurship.” Cambridge University Press.

Puri, Manju, and Rebeca Zarutskie. 2012. "On the Lifecycle Dynamics of Venture-Capital- and Non-Venture-Capital-Financed Firms." Journal of Finance 67(6): 2247-93.

Qian, Yingyi, and Chenggang Xu. 1998. "Innovation and Bureaucracy under Soft and Hard Budget Constraints." Review of Economic Studies 65(1): 151-64.

- Rajan, Raghuram G. 2012. "Presidential Address: The Corporation in Finance." Journal of Finance 67(4): 1173-1217.

Ries, Eric. 2011. The Lean Startup: How Today's Entrepreneurs Use Continuous Innovation to Create Radically Successful Businesses. Crown Business Publishing.

Ritter, Jay R. 2014. "Initial Public Offerings: Updated Statistics."

Robb, Alicia M., and David T. Robinson. 2014. "The Capital Structure Decisions of New Firms." Review of Financial Studies 27(1): 153-79.

Rosenberg, Nathan. 1994. "Economic Experiments." In Chap. 5 in Exploring the Black Box: Technology, Economics, and History. Cambridge University Press.

Sahlman, William A. 1990. "The Structure and Governance of Venture-Capital Organizations." Journal of Financial Economics 27(2): 473-521.

Sahlman, William A. 2010. "Risk and Reward in Venture Capital." Harvard Business School Background Note 811-036.

Sahlman, William, Ramana Nanda, Joseph B. Lassiter III, and James McQuade. 2012. "TerraPower." Harvard Business School Case Study 813-108.

-Saint-Paul, Gilles. 2002. "Employment Protection, International Specialization, and Innovation." European Economic Review 46(2): 375-95.

Samaniego, Roberto M. 2006. "Employment Protection and High-Tech Aversion." Review of Economic Dynamics 9(2): 224-41.

-Samila, Sampsa, and Olav Sorenson. 2011. "Venture Capital, Entrepreneurship and Economic Growth." Review of Economics and Statistics 93(1): 338-49.

Scherer, F. M., and Dietmar Harhoff. 2000. "Technology Policy for a World of Skew-distributed Outcomes." Research Policy 29(4-5): 559-66. 
Schumpeter, Joseph. 1911 [1934]. The Theory of Economic Development: An Inquiry into Profits, Capital, Credit, Interest and the Business Cycle. Cambridge, MA: Harvard University Press.

Schumpeter, Joseph. 1943. Capitalism, Socialism, and Democracy. Harper Brothers, New York, NY.

Shane, Scott A. 2009. Fool's Gold? The Truth behind Angel Investing in America. Oxford University Press.

Stern, Scott. 2005. "Economic Experiments: The Role of Entrepreneurship in Economic Prosperity." In Understanding Entrepreneurship: A Research and
Policy Report, edited by Carl J. Schramm, 16-20. Ewing Marion Kauffman Foundation.

Thomke, Stefan H. 2003. Experimentation Matters: Unlocking the Potential of New Technologies for Innovation. Boston, MA: Harvard Business School Press.

-Tian, Xuan. 2011. "The Causes and Consequences of Venture Capital Stage Financing." Journal of Financial Economics 101(1): 132-59.

-Weitzman, Martin. 1979. "Optimal Search for the Best Alternative." Econometrica 47(3): 641-54.

Wilson, Fred. 2011. "Airbnb." March 16. http:// www.avc.com/a_vc/2011/03/airbnb.html. 